\title{
Studying the Risks of Cotton Cooking Oil Fumes on the Lung and Liver of Rats and the Protective Role of (Vitamin E Alphatocopherol )
}

\author{
Fahmy GAD GAD ELsaid \\ Zoology Department, Faculty of Science, Mansoura University, Mansoura, Egypt.
}

\begin{abstract}
Fumes emitted from edible vegetable cooking oils during stir- and deep-frying are important contributors to indoor air pollution. Indoor air pollution may be increase the lung and liver cancer in Egypt in 2005. Therefore, the present study was undertaken to investigate the effects of Egyptian cotton cooking oil fumes on rats. The exposed rats for 30 and 60 days to cotton oil fumes showed a significant increase in the lung and liver malondialdehyde levels which accompanied with a significant decrease in glutathione content. Also, there was a significant decrease in lung and liver superoxide dismutase, catalase, glutathione s-transferase activities. As well as, there was a significant decrease in serum amino acids levels, lung and liver nucleic acids and total proteins. These changes were obviously after 60 days than that of 30 days of exposure. DNA change was clear in the lungs of rats after cotton oil fumes exposed as showed by the differential display technique, P53 primer which used to study the expression of the p35 gene as well as to confirm and amplify these changes after oil fumes exposure. Band with different molecular weights were observed after the exposure and in protected groups but not presented in the control. More characterization for the changes had been carried out in the animal on two levels, one the DNA using RAPD-PCR and the other on the protein level using SDS-PAGE techniques. Also, vitamin E ameliorates these abnormalities to extent limit in all cases in this work.
\end{abstract}

Keywords: cooking oil fumes, cotton oil, polycyclic aromatic hydrocarbons (PAHs), superoxide dismutase (SOD), catalase (CAT), glutathione s-transferase (GST), glutathione (GSH), lipid peroxidation (MDA), amino and nucleic acids, SDSPAGE, RAPD-PCR, Differential Display, Vitamin E, rat, lung, liver.

\section{Introduction}

Fumes from cooking oils were found to be mutagenic and several polycyclic aromatic hydrocarbons (PAHs), (benzo $(a)$ pyrene (B (a) P), benz (a) anthracene (B (a)A), and dibenz $(a, h)$ anthracene (DB (ah)A) (Wu et al.,1998), and nitrogen polyaromatic hydrocarbons (NPAHS) were identified (Tsai and Huang 1993). These PAHs such as oil fumes obtained in experimental settings and in air samples from kitchens (Li et al., 1994, Mumford et al., 1995 and Chaing et al., 1997).However, exposure to air pollutants is associated with adverse effects on respiratory health, such as chronic obstructive pulmonary disease, exacerbation of asthma, and lung cancer
(Cohen and Pope 1995, and Seaton et al., 1995). Moreover, B[a]P has been identified in urban air particulates, cigarette smoke, and cooking oil fumes (COF) (Li et al,, 1994,Witschi et al., 1997, and Kuo et al. 1998), and it increases the incidence of lung tumor in rodents (Iwagawa et al., 1989). COF are generated not only during Chinese-style cooking but also during Western-style deep-frying (Coggon et al., 1986), and the Egyptian-style cooking also generates COF. The biological effects of COF on human lung epithelial CL3 cells, namely is the inhibition of cell growth and induction of oxidative stress (Wu et al., 1999 and Tunga et al., 2001). So, daily 
exposure to cooking oil fumes in Taiwan might be an important risk factor in the etiology of lung cancer; this may be due to the mutagenicity or carcinogenicity of cooking oil fumes (Shields et al., 1995, Wu et al., 1999 and Ko et al., 2000). The proinflammatory properties of reactive oxygen species (ROS) in the lung include endothelial cell damage, lipid peroxidation and oxidation, DNA damage (Mossman and Churg 1998, Zhang et al., 1999), the release of TNF-a and IL-1b, and the formation of peroxynitrite (Dorger et al., 2002).

An imbalance between the amounts of ROS and antioxidant defenses is characteristic of lung diseases. Free radical-induced oxidative damage has been implicated in the pathogenesis of a number of injury and diseases states (Max 1987).In normal conditions, cells cope with free radicals using such enzymatic and nonenzymatic defenses as superoxide dismutase (SOD), glutathione s-transferase (GST), catalase (CAT), glutathione peroxidase (GPx) and glutathione (GSH) (Gul et al., 2000). SOD catalyzes the dismutation of the superoxide anion $\left(\mathrm{O}_{2}{ }^{-}\right)$into hydrogen peroxide $\left(\mathrm{H}_{2} \mathrm{O}_{2}\right)$ and CAT which is found in many types of cells including erythrocytes, converts $\mathrm{H}_{2} \mathrm{O}_{2}$ to water and molecular oxygen (Akyol et al., 2001). Remarkable progress has been made in the last decade in defining the toxicological and other potential physiological roles of GST (Strange et al., 2001). In addition, other electrophilic foreign compounds (xenobiotics) may be detoxified in a reaction catalyzed by a group of enzymes named glutathione s-transferases, by which they are conjugated with GSH (Den Boer et al., 1990b and Sweet and Blanchard 1991). Glutathione is involved in the conjugation and detoxification of several types of compounds that cause toxicity and carcinogenesis (Teramoto et al., 1996), as well known that GSH plays an important role in the defense mechanism of the lung (Zhang et al., 1999 and Govindaraju et al., 2003). Damage to the genetic material induced by ROS has been studied from various aspects and these may be include chemical analysis of DNA composition or DNA metabolites in body fluids (Ames and Gold 1991) and, the ability to initiate transformation (Larson et al., 1992), changes in chromosome structure (Phillips et al., 1984), unusual expression of genes (Suzuki and Hei 1996), changes of cell phenotype and analysis of DNA sequences (McBride et al., 1991). As the increased lipid peroxidation generate epoxides that may spontaneously react with nucleophilic centers in the cell and thereby covalently bind to DNA, RNA, and protein (Yin et al., 1995 and Rikans and Hornbrook 1997). Such a reaction may leads to cytotoxicity, mutagenicity, and /or carcinogenicity (Oesch 1984).

Vitamin E ( $\alpha$-tocopherol) is the most important lipid- soluble chain-breaking antioxidant in tissues, red cells and plasma (Burton and Traber 1990 and Quiles et al., 2002). It is also known to interrupt the biochemical reactions associated with lipid peroxidation, and has been shown to effectively inhibit iron-induced lipid peroxidation in a multitude of studies (Wagner et al., 1996 and Iqbal et al.,1998).Cellular and molecular studies provided a possible mechanism whereby, vitamin E may exert its action, namely by scavenging peroxyradicals and thereby acting as a chainbreaking antioxidant (Serbinova et al., 1991).Vitamin E protects polyunsaturated fatty acids (PUFAs) and protein thiol groups against oxidation (Ferre et al., 2001).

\section{Material and methods}

\section{Animals and exposures:}

Forty male albino rats weighting 160 $-180 \mathrm{~g}$ were used in the present experiment. All the rats were caged and ad libitum fed without water restriction. The animals were divided into four groups, as follows: (1) control, (2) control oil treated (orally administered with the cotton oil at 0.04 $\mathrm{ml} / 100 \mathrm{~g}$ ), (3) fumes exposed and (4) fumes exposed and vitamin $\mathrm{E}$ protected group. Each group was subdivided into two subgroups (30 and 60 days).

\section{Cotton oil fumes exposure:}

Animals were housed in a glass chamber of volume $\left(0.072 \mathrm{~m}^{3}\right)$, with dimension $(30 \mathrm{~cm}$ width, $60 \mathrm{~cm}$ length and $40 \mathrm{~cm}$ height). For production of fumes, 
about $250 \mathrm{ml}$ of cooking cotton oil was daily preheated on digital hot plate to approximately $280 \pm 20^{\circ} \mathrm{c}$. Consequently, rats inhale oil fumes $(30 \mathrm{~min} / \mathrm{d})$ for both experimental periods (30 and 60 days).

\section{Vitamin E protection:}

Vitamin E was dissolved in cotton oil and orally administered at $0.43 \mathrm{mg} / 100 \mathrm{~g}$ body weight before exposure to the cooking oil fumes.

\section{Serum and tissue homogenates:}

After 30 and 60 days, rats were decapitated, blood samples were collected and sera were separated and stored at $20^{\circ} \mathrm{c}$. Lung and liver samples were taken, homogenized and diluted in saline solution $(0.9 \%)$ to make $(10 \%)$ and stored at $-20^{\circ} \mathrm{c}$ for later analysis.

\section{Methodology:}

a- Biochemical parameters:

Lipid peroxidation was measured in lung and liver homogenates according to the modification of the method of Ohkawa et al., (1979). GST enzyme activity in rat lung and liver was determined according to the method of Habig and Jakoby (1981). CAT activity was measured according to the method of Aebi (Aebi, 1984). Total SOD activity was assessed according to the method of (Nikishimi et al., 1972).GSH level of the lung and liver homogenates were measured by the method of (Prins and Loose 1969).Total protein content was determined by the method described by (Henery 1964).Total DNA and RNA contents were determined by the methods described by Dishe and Schwarz (1977) and Mejbaum (1939) respectively.

Phospholipids level was determined according to Baginiski et al., (1972) and total lipids level measured by the method of Frings et al., (1972). Amino acid determination was performed according to the method of Winder and Eggum (1966). The system used for the analysis was High Performance Amino Acid Analyzer, (Sykam, GMBH Amino Acid Analyzer, Germany).

\section{$b$-Molecular techniques:}

Extraction of DNA and RNA:

DNA was extracted from fresh lung tissues according to modified mini-prep CTAB method of Harris (1995).Total RNAs of the lung tissue prepared using the RNAeasy kit according to manufacturer's instructions (QIAGEN). The RNA was dissolved in DEPC-treated water, and total RNA analyzed on $1.2 \%$ agarose gel.

Differential display analysis and RAPDPCR:

$$
\text { Random Amplified Polymorphic }
$$

DNA (RAPD) was carried out using random primer (A) according to Williams et al., (1993). Primer used in the differential display analysis was synthesized in MWG Biotech (P35 forward) according to White et al., (1990).

\begin{tabular}{|l|l|l|}
\hline $\begin{array}{l}\text { Primer } \\
\text { name }\end{array}$ & Sequence 5 - 3 & Reference \\
\hline A & $\begin{array}{l}\text { CAG GCC CTT CCA } \\
\text { GCA CCC AC }\end{array}$ & $\begin{array}{l}\text { A. Ali and E. } \\
\text { Hafez (2005) }\end{array}$ \\
\hline P35 & $\begin{array}{l}\text { AAATGAAGCTCTGC } \\
\text { ATCCTGC }\end{array}$ & $\begin{array}{l}\text { (Liu. et al., } \\
\text { 2004) }\end{array}$ \\
\hline
\end{tabular}

Total soluble protein extraction and SDSPAGE:

SDS-PAGE was carried out according to Laemmli (1970) and the soluble protein extracts were prepared as described by Nick et al., (1995).

\section{Statistical analysis}

The findings were expressed as the mean \pm SD. Statistical and correlation analyses were undertaken using the Oneway ANOVA with post-hoc LSD (Least Significant Difference) test. A P value < 0.05 was accepted statistically significant. Statistical analysis was performed with Statistical Package for the Social Sciences for Windows (SPSS, version 10.0, Chicago, IL, USA).

\section{Results}

In the present study, table (1) indicates a significant increase in lung and liver lipid peroxidation (MDA) levels in cotton oil fumes exposed rats as compared to the control rats, and significant decrease 
of serum GSH content in lung and liver tissues. Also decrease in total lipids and phospholipids levels in both exposed groups.

Table $(2 a, b)$ showed decrease of serum amino acids level in the exposed rats and these more obviously in 60 days group than in 30 days one.

DNA, RNA and total protein contents significantly decrease in the COF exposed animals, but this decrease showed amelioration for $\mathrm{COF}$ exposed and protected groups as in table (3).

In addition, lung and liver CAT, GST and SOD showed significant decrease in the COF exposed groups as in table (4). Also serum phospholipids, total lipids and total protein contents decrease significantly in the COF exposed groups as in table (5).

The molecular study had been carried out at the 60 days groups (control, control oil, fumes exposed and fumes exposed and protected) because the changes were more obvious. The total RNA was extracted and subjected to RT-PCR using P35 as an arbitrary primer random primer to examine the expression of the induced gene(s) in the rat lung, which was exposed to the cotton oil fumes. The results obtained by the PCR showed that all rats gave two bands in low molecular weights (ranging from 100-150 bp) but the exposed rats, lungs contain a band with molecular weight more than 500 bp as shown in Fig. (1). The obtained results suggest the presence of lung cancer which was improved by the expression of the P35 in the exposed rat but might not expressed enough in the other rats.

As in fig.(2) for examination if any changes had been carried out on the DNA level RAPD-PCR was performed on the DNA of that samples. The results obtained by the RAPD-PCR showed differentiation between the control and cotton oil fumes exposed and fumes exposed and protected groups respectively.

Seven bands with different molecular weight were observed with samples named cotton oil fumes exposed and fumes exposed and protected groups, bands observed in the control rats was completely differ when compared with the others. Six bands were presented in all groups but only one band was present in the fumes exposed and fumes exposed and protected groups.

The serum of the four groups was also examined on protein level as in (fig.3); the protein pattern showed that the cotton oil fumes exposed and fumes exposed and protected groups gave a protein pattern which was differing from that of control group. The protein pattern was presented in two bands with molecular weight approximately 17 and $15 \mathrm{kDa}$ respectively. The presence of such protein may be indication to the band that obtained by the differential display (500bp) as in fig (1).

Table (1): Lung ${ }^{1}$ and Liver $^{2}$ GSH, MDA, Total lipids, Phospholipids levels.

\begin{tabular}{|c|c|c|c|c|c|c|c|c|c|}
\hline \multirow{3}{*}{$\begin{array}{l}\text { GSH content } \\
\text { (mg/g }\end{array}$} & & \multicolumn{2}{|c|}{ Control } & \multicolumn{2}{|c|}{ Control + oil } & \multicolumn{2}{|c|}{ Fumes exposed } & \multicolumn{2}{|c|}{ Fumes exposed+ protected } \\
\hline & & 30 & 60 & 30 & 60 & 30 & 60 & 30 & 60 \\
\hline & $\begin{array}{l}1 \\
2\end{array}$ & $\begin{array}{l}4.3 \pm .75 \\
3.5 \pm .15\end{array}$ & $\begin{array}{l}3.5 \pm .18 \\
3.1 \pm .05\end{array}$ & $\begin{array}{l}2.9 \pm .13^{* \star *} \\
2.2 \pm .11^{\star * *}\end{array}$ & $\begin{array}{l}2.8 \pm .65^{* *} \\
1.9 \pm .09^{\star * \star}\end{array}$ & $\begin{array}{l}2.1 \pm .22^{* \star *} \\
1.2 \pm .07^{\star \star *}\end{array}$ & $\begin{array}{l}1.2 \pm .02^{* \star *} \\
.86 \pm .08^{\star * *}\end{array}$ & $\begin{array}{l}2.5 \pm .21^{* * *} \\
2.5 \pm .21^{\star * *}\end{array}$ & $\begin{array}{l}2.8 \pm .37^{* *} \\
1.9 \pm .09^{* * *}\end{array}$ \\
\hline MDA (nmol/g) & $\begin{array}{l}1 \\
2\end{array}$ & $\begin{array}{l}55.9 \pm 4.6 \\
63.3 \pm .77\end{array}$ & $\begin{array}{l}57.3 \pm 1.8 \\
83.8 \pm 2.9\end{array}$ & $\begin{array}{c}73.3 \pm 2.3^{\star * *} \\
100.3 \pm 1.9^{\star * *}\end{array}$ & $\begin{array}{c}86.4 \pm 7.6^{\star \star \star} \\
122.7 \pm 3.7^{\star \star \star}\end{array}$ & $\begin{array}{l}117.13 \pm 3.3^{\star * *} \\
213.7 \pm 8.3^{* * *}\end{array}$ & $\begin{array}{c}188.2 \pm 7^{* \star *} \\
284.3 \pm 10.2^{* \star *}\end{array}$ & $\begin{array}{c}62.8 \pm 8^{*} \\
112.9 \pm 7.1^{\text {***}}\end{array}$ & $\begin{array}{c}82.6 \pm 3.9^{* * *} \\
140.3 \pm 8.6^{\star * *}\end{array}$ \\
\hline $\begin{array}{ll}\text { Total } & \text { lipids } \\
(\mathrm{mg} / \mathrm{g}) & \end{array}$ & $\begin{array}{l}1 \\
2\end{array}$ & $\begin{array}{c}173.4 \pm 3.7 \\
247.1 \pm .13 .2\end{array}$ & $\begin{array}{l}179.8 \pm 15.3 \\
277.2 \pm 6.9\end{array}$ & $\begin{array}{l}180.6 \pm 33.5^{\star \star \star} \\
349.2 \pm 13.2^{\star \star \star}\end{array}$ & $\begin{array}{c}193.2 \pm 5.9 \\
565.4 \pm 4.9^{\star \star *}\end{array}$ & $\begin{array}{c}134.7 \pm 3.2^{\star \star \star} \\
207.8 \pm 11.9^{\star \star *}\end{array}$ & $\begin{array}{c}99.7 \pm 9.1^{\star \star *} \\
129.5 \pm 7.0^{\star \star *}\end{array}$ & $\begin{array}{c}138.9 \pm 5.9 \\
150.5 \pm 11.2^{\text {** }}\end{array}$ & $\begin{array}{r}124.77 \pm 4.5^{\star \star \star} \\
116.6 \pm 6.1^{\star \star \star}\end{array}$ \\
\hline $\begin{array}{l}\text { Phospholipids } \\
(\mu \mathrm{g} / \mathrm{g})\end{array}$ & $\begin{array}{l}1 \\
2\end{array}$ & $\begin{array}{c}422.8 \pm 70.4 \\
1376.1 \pm 65.5\end{array}$ & $\begin{array}{c}457.8 \pm 78.4 \\
1615.2 \pm 49.8\end{array}$ & $\begin{array}{c}800.4 \pm 32.4^{* \star *} \\
1924.4 \pm 46.04^{* \star *}\end{array}$ & $\begin{array}{l}1070.8 \pm 118.4^{* * *} \\
2430.4 \pm 269.8^{* * *}\end{array}$ & $\begin{array}{c}338.02 \pm 48.1^{*} \\
1028.6 \pm 51.5^{\star * *}\end{array}$ & $\begin{array}{l}211.7 \pm 12.7^{\star \star *} \\
738.7 \pm 45.5^{\star * *}\end{array}$ & $\begin{array}{c}351.1 \pm 15.1 \\
961.6 \pm 28.7^{\star \star *}\end{array}$ & $\begin{array}{c}280.8 \pm 11.6^{* \star *} \\
649.8 \pm 594.8^{* * *}\end{array}$ \\
\hline
\end{tabular}

The $\mathrm{P}$ value is significant at the $.05^{\star}, .01^{* *}$, and $.001^{* \star *}$ levels. 
Table (2a): Serum essential amino acids $(\mu \mathrm{g} / \mathrm{ml})$.

\begin{tabular}{|c|c|c|c|c|c|c|c|c|}
\hline & \multicolumn{2}{|c|}{ Control } & \multicolumn{2}{|c|}{ Control + oil } & \multicolumn{2}{|c|}{ Fumes exposed } & \multicolumn{2}{|c|}{ Fumes exposed+ protected } \\
\hline & 30 & 60 & 30 & 60 & & 60 & so r & r $=0$ \\
\hline & $2.4 \pm .18$ & $1.9 \pm .08$ & $1.8 \pm .09^{* \star *}$ & $1.7 \pm .09$ & $1.4 \pm .12^{* * *}$ & $.84 \pm .06^{* * *}$ & $1.8 \pm .08^{* * *}$ & $1.6 \pm .09^{* * *}$ \\
\hline Histidine & $72.4 \pm 1.7$ & $63.9 \pm 2.3$ & $57.8 \pm 1.1^{\star \star \star}$ & $51.4 \pm .90^{\star \star \star}$ & $33.9 \pm .74^{\star \star \star}$ & $16.7 \pm .49^{\star \star \star}$ & $42.9 \pm 2.06^{\star \star \star}$ & $28.1 \pm .76^{\star * \star}$ \\
\hline Isolet & & $27.8 \pm 1$. & & & & & & $17.9 \pm 1.26^{\star \star \star}$ \\
\hline Leuci & $85.5 \pm .79$ & $71.8 \pm .6$ & $62.2 \pm 1.1^{* \star *}$ & $57.6 \pm .96^{\star \star \star}$ & $41.8 \pm 2.1^{\star \star \star}$ & $34.1 \pm .31^{* \star *}$ & $52.8 \pm .49^{\star \star \star}$ & $42.3 \pm 1.5^{\star \star \star}$ \\
\hline & & & & $2.9 \pm .2$ & & & & $\pm .23^{\star \star \star}$ \\
\hline Methi & $15.7 \pm .46$ & $14.1 \pm .70$ & $11.9 \pm .49^{* \star *}$ & $10.7 \pm .55^{\star \star \star}$ & $7.7 \pm .47^{\star \star *}$ & $4.3 \pm .09^{\star \star \star}$ & $31^{* \star *}$ & $9.1 \pm .24^{* * *}$ \\
\hline Phe & & & & $4^{\star \star \star}$ & $42.2 \pm 2.7^{* * *}$ & $34.6 \pm .47$ & & $7 \pm .79^{\star \star \star}$ \\
\hline Therioni & $64.3 \pm .69$ & $56.1 \pm 3.6$ & $51.3 \pm 1.9^{\star \star \star}$ & $40.6 \pm 13.9^{\star \star \star}$ & $24.5 \pm .45^{\star \star \star}$ & $15.9 \pm .32^{\star \star \star}$ & $\pm .91^{\star \star \star}$ & $20.8 \pm 1.2^{\star * \star}$ \\
\hline Valine & $60.7 \pm .50$ & $52.8 \pm 1.0$ & $49.5 \pm 1.8^{\star \star \star}$ & $44.6 \pm 2.3^{* \star *}$ & $25.1 \pm . .82^{\star \star \star}$ & $19.4 \pm 1.9^{\star \star \star}$ & $36.7 \pm .79^{\star \star \star}$ & $25.8 \pm 1.2^{\star \star \star}$ \\
\hline
\end{tabular}

The $\mathrm{P}$ value is significant at the $.05^{*}, .01^{* *}$, and $.001^{* * *}$ levels.

Table (2b): Serum nonessential amino acids $(\mu \mathrm{g} / \mathrm{ml})$.

\begin{tabular}{|c|c|c|c|c|c|c|c|c|}
\hline & \multicolumn{2}{|c|}{ Control } & \multicolumn{2}{|c|}{ Control + oil } & \multicolumn{2}{|c|}{ Fumes exposed } & \multicolumn{2}{|c|}{ Fumes exposed+ protected } \\
\hline & 30 & 60 & 30 & 60 & 30 & 60 & 30 & 60 \\
\hline Alanine & $58.3 \pm .68$ & $52.9 \pm .95$ & $48.8 \pm 1.5^{\star \star \star}$ & $36.1 \pm .62^{\star \star \star}$ & $22.7 \pm 1.0^{\star \star \star}$ & $19.4 \pm .71^{\star \star \star}$ & $37.6 \pm 1.2^{\star \star \star}$ & $29.2 \pm 1.6^{\star \star \star}$ \\
\hline $\begin{array}{c}\text { Aspartic } \\
\text { acid }\end{array}$ & $34.2 \pm .59$ & $30.8 \pm 1.0$ & $25.5 \pm .82^{* * *}$ & $21.9 \pm 1.4^{* * *}$ & $23.2 \pm 3.4^{* * *}$ & $17.8 \pm 1.1^{* \star *}$ & $25.0 \pm 1.4^{\star \star *}$ & $19.6 \pm .78^{* * *}$ \\
\hline Cystine & $36.2 \pm .44$ & $29.9 \pm 1.7$ & $26.8 \pm 1.2^{\star \star \star}$ & $22.9 \pm 2.1^{* * *}$ & $20.2 \pm .70^{* * *}$ & $15.2 \pm 1.2^{\star \star *}$ & $28.7 \pm 1.8^{\star \star *}$ & $20.5 \pm .62^{* \star \star}$ \\
\hline $\begin{array}{c}\text { Glutamic } \\
\text { acid }\end{array}$ & $91.4 \pm 1.2$ & $86.2 \pm 1.7$ & $72.9 \pm 1.4^{\star \star \star}$ & $65.3 \pm 2.8^{\star * \star}$ & $42.8 \pm 2.5^{\star \star \star}$ & $39.5 \pm .94^{\star \star \star}$ & $58.9 \pm 2.4^{\star \star *}$ & $53.8 \pm 1.4^{\star \star \star}$ \\
\hline Glycine & $46.3 \pm .54$ & $39.5 \pm 1.2$ & $34.6 \pm .61^{* \star \star *}$ & $24.3 \pm .97^{* * *}$ & $21.8 \pm .89^{* \star *}$ & $15.9 \pm .49^{* * *}$ & $34.6 \pm .61^{* * *}$ & $23.9 \pm 1.3^{* \star *}$ \\
\hline Proline & $108.9 \pm 1.1$ & $85.9 \pm 1.7$ & $86.6 \pm 5.2^{\star \star \star}$ & $69.2 \pm .63^{\star \star \star}$ & $71.7 \pm .49^{\star \star *}$ & $56.8 \pm 3.7^{* \star *}$ & $86.9 \pm 4.3^{\star * *}$ & $65.6 \pm 3.1^{\star * *}$ \\
\hline Seriene & $53.5 \pm .77$ & $41.7 \pm 1.1$ & $38.9 \pm 1.2^{\star \star \star}$ & $30.5 \pm .53^{* * *}$ & $26.3 \pm 1.7^{* \star *}$ & $12.5 \pm .33^{\star \star *}$ & $37.3 \pm .80^{\star \star *}$ & $23.1 \pm 1.2^{\star \star \star}$ \\
\hline Tyrosine & $47.9 \pm 13.0$ & $35.4 \pm .23$ & $32.9 \pm 1.2^{* \star *}$ & $24.3 \pm 2.8^{* \star *}$ & $24.3 \pm .63^{* * *}$ & $15.3 \pm .76^{* * *}$ & $34.0 \pm .85^{* * *}$ & $26.2 \pm 1.7^{* *}$ \\
\hline
\end{tabular}

The $\mathrm{P}$ value is significant at the $.05^{*}, .01^{* *}$, and $.001^{* * *}$ levels.

Table (3): Lung ${ }^{1}$ and Liver ${ }^{2}$ DNA, RNA and total protein contents.

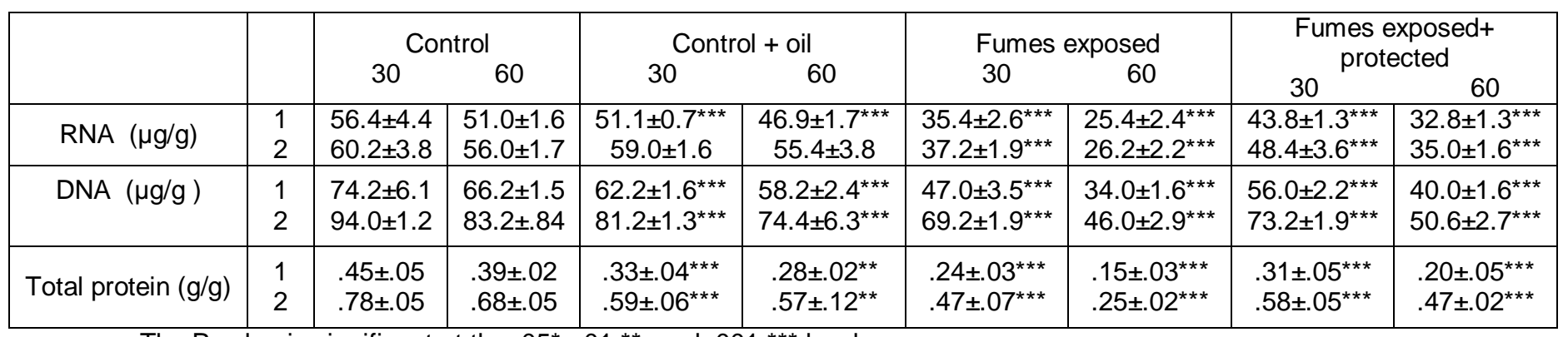

The $\mathrm{P}$ value is significant at the $.05^{\star}, .01^{* *}$, and $.001^{{ }^{* *}}$ levels.

Table (4): Lung ${ }^{1}$ and Liver ${ }^{2}$ CAT, GST and SOD activities.

\begin{tabular}{|c|c|c|c|c|c|c|c|c|c|}
\hline \multirow{3}{*}{ CAT(Unit/mg) } & \multirow[b]{3}{*}{$\begin{array}{l}1 \\
2\end{array}$} & \multicolumn{2}{|c|}{ Control } & \multicolumn{2}{|c|}{ Control + oil } & \multicolumn{2}{|c|}{ Fumes exposed } & \multirow{2}{*}{\multicolumn{2}{|c|}{$\begin{array}{l}\text { Fumes exposed + protected } \\
30\end{array}$}} \\
\hline & & 30 & 60 & 30 & 60 & & 60 & & \\
\hline & & $\begin{array}{l}18.8 \pm .94 \\
99.8 \pm 1.9\end{array}$ & $\begin{array}{l}18.2 \pm .75 \\
87.5 \pm 2.3\end{array}$ & $\begin{array}{l}16.1 \pm .93^{\star * \star} \\
71.8 \pm .92^{\star \star \star}\end{array}$ & $\begin{array}{l}15.3 \pm .73^{\star \star \star} \\
64.0 \pm 2.0^{\star \star \star}\end{array}$ & $\begin{array}{l}13.0 \pm .35^{\star \star \star} \\
44.0 \pm 1.4^{\star \star \star}\end{array}$ & $\begin{array}{l}11.6 \pm .43^{\star * \star} \\
36.4 \pm 2.0^{\star \star \star}\end{array}$ & $\begin{array}{l}14.3 \pm .39^{* * *} \\
50.9 \pm 1.8^{\star * *}\end{array}$ & $\begin{array}{l}13.1 \pm .35^{\star \star \star} \\
42.9 \pm 2.5^{\star \star \star}\end{array}$ \\
\hline $\begin{array}{c}\text { GST } \\
\text { (Unit/mg) }\end{array}$ & $\begin{array}{l}1 \\
2 \\
\end{array}$ & $\begin{array}{l}4.5 \pm .34 \\
5.7 \pm .61\end{array}$ & $\begin{array}{l}5.3 \pm .45 \\
5.8 \pm .51\end{array}$ & $\begin{array}{l}3.3 \pm .40^{* \star *} \\
4.7 \pm .26^{* \star *}\end{array}$ & $\begin{array}{l}3.4 \pm .44^{* \star *} \\
3.9 \pm .21^{\star \star \star}\end{array}$ & $\begin{array}{l}1.9 \pm .17^{\star \star \star} \\
3.2 \pm .69^{\star \star *}\end{array}$ & $\begin{array}{l}.79 \pm .09^{\star \star \star} \\
1.7 \pm .07^{\star \star \star}\end{array}$ & $\begin{array}{c}4.2 \pm .32 \\
3.9 \pm .11^{\star \star \star}\end{array}$ & $\begin{array}{l}2.9 \pm .19^{\star * \star} \\
2.9 \pm .12^{\star * \star}\end{array}$ \\
\hline $\begin{array}{l}\text { SOD } \\
\text { (Unit/mg) }\end{array}$ & $\begin{array}{l}1 \\
2\end{array}$ & $\begin{array}{l}84.5 \pm 4.2 \\
65.4 \pm 5.2\end{array}$ & $\begin{array}{l}78.9 \pm 5.3 \\
54.5 \pm 2.5\end{array}$ & $\begin{array}{l}71.4 \pm 1.1^{* * *} \\
54.9 \pm 3.2^{\star * *}\end{array}$ & $\begin{array}{l}63.3 \pm 4.1^{* \star *} \\
41.6 \pm .99^{* \star *}\end{array}$ & $\begin{array}{l}43.9 \pm 3.7^{* * *} \\
29.1 \pm 1.3^{* * *}\end{array}$ & $\begin{array}{l}31.6 \pm 2.6^{* * *} \\
20.7 \pm 1.6^{\star * \star}\end{array}$ & $\begin{array}{l}51.3 \pm 3.1^{* \star *} \\
44.1 \pm 4.3^{\star \star *}\end{array}$ & $\begin{array}{l}42.0 \pm 2.7^{\star * *} \\
29.6 \pm 1.8^{\star * *}\end{array}$ \\
\hline
\end{tabular}

The $\mathrm{P}$ value is significant at the $.05^{\star}, .01^{\star \star}$, and $.001^{\star \star *}$ levels. 
Table (5): Serum phospholipids, total lipids and total proteins.

\begin{tabular}{|c|c|c|c|c|c|c|c|c|}
\hline \multirow{3}{*}{$\begin{array}{c} \\
\begin{array}{c}\text { Phospholipids } \\
(\mu \mathrm{g} / \mathrm{dl})\end{array}\end{array}$} & \multicolumn{2}{|c|}{ Control } & \multicolumn{2}{|c|}{ Control + oil } & \multicolumn{2}{|c|}{ Fumes exposed } & \multicolumn{2}{|c|}{ Fumes exposed+ } \\
\hline & 30 & 60 & 30 & 60 & & 60 & & 60 \\
\hline & $218.9 \pm 26.2$ & $215.2 \pm 5.5$ & $171.0 \pm 20.1^{* * *}$ & $149.3 \pm 18.2^{* * *}$ & $90.3 \pm 1.5^{\star \star \star}$ & $71.31 \pm 5.4^{* * *}$ & $102.2 \pm 2.4^{\star \star \star}$ & $99.2 \pm 4.9^{* * *}$ \\
\hline $\begin{array}{c}\text { Total lipids } \\
(\mathrm{mg} / \mathrm{dl})\end{array}$ & $908.7 \pm 33.9$ & $983.9 \pm 37.4$ & $1083.1 \pm 41.3^{\star \star \star}$ & $1233.1 \pm 41.9^{\star \star \star}$ & $\begin{array}{c}630.9 \pm 101 \\
.7^{* * *}\end{array}$ & $480.1 \pm 10.3^{* \star *}$ & $834.8 \pm 32.4$ & $661.9 \pm 36.4^{\star \star \star}$ \\
\hline $\begin{array}{c}\text { Total proteins } \\
(\mathrm{g} / \mathrm{dl})\end{array}$ & $11.8 \pm .25$ & $11.9 \pm .30$ & $9.5 \pm .35^{\star * *}$ & $9.3 \pm .51^{* * *}$ & $7.7 \pm .34^{\star * *}$ & $6.4 \pm .21^{\star \star \star}$ & $10.2 \pm .13^{* \star *}$ & $8.9 \pm .69^{\star * *}$ \\
\hline
\end{tabular}

The $\mathrm{P}$ value is significant at the $.05^{\star}, .01^{* *}$, and $.001^{* \star *}$ levels.

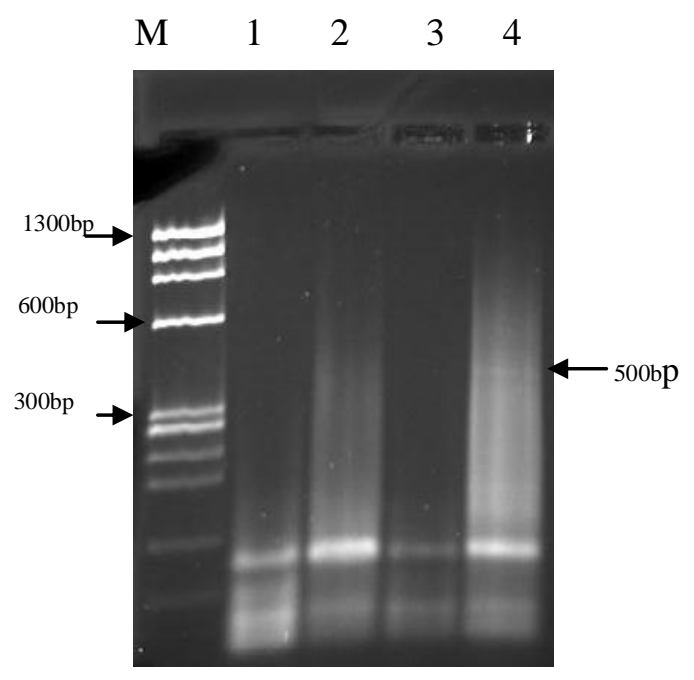

Fig. (1): Differential display for the four samples rat blood serum, lane 1: Pha X DNA marker, Lane 1-4 were, Control, Control Oil, Cotton Oil Fumes Exposed and Protected and Cotton Oil Fumes Exposed, respectively.

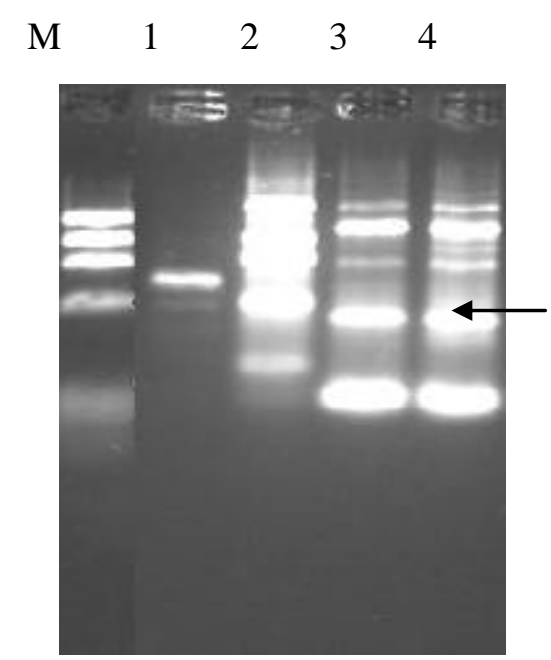

Fig. (2): RAPD-PCR for lung DNA, lane M: pha X DNA marker, lane 1-4 were Control, Control Oil, Cotton Oil Fumes Exposed and Cotton Oil Fumes Exposed and Protected, respectively. 
Fahmy GAD GAD ELsaid

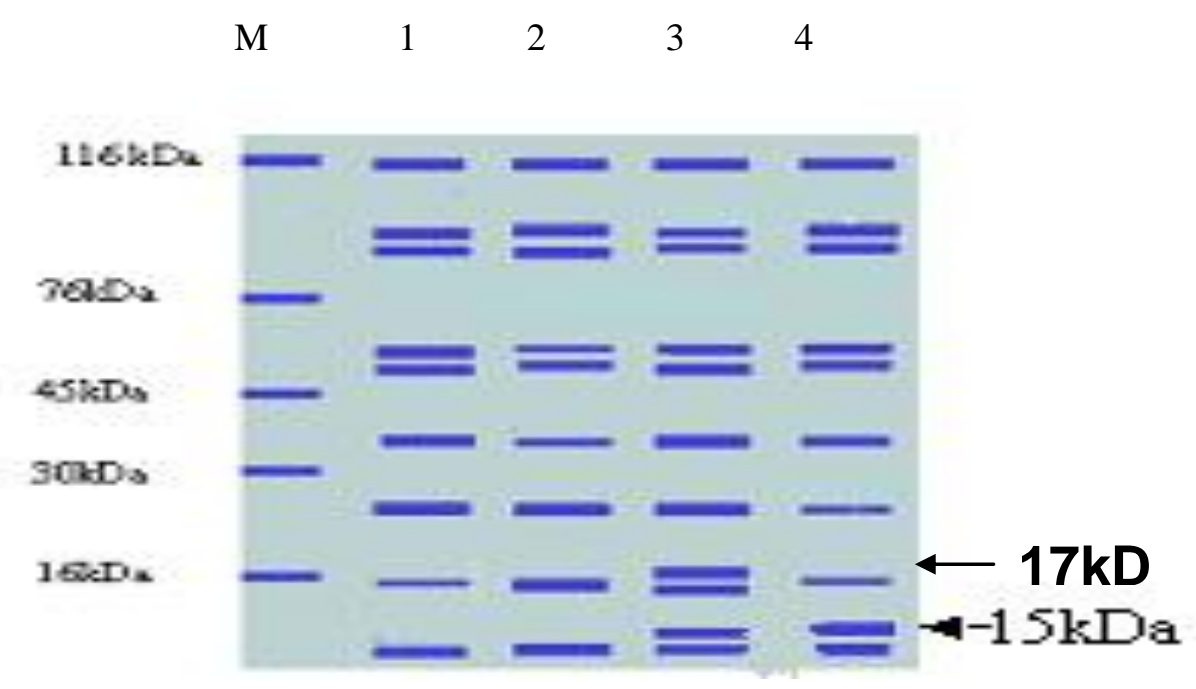

Fig. (3): SDS-PAGE for serum protein, lane 1: pha $X$ Protein marker, lane 1-4 were Control, Control Oil, Cotton Oil Fumes Exposed, Cotton Oil Fumes Exposed and Protected, respectively.

\section{Discussion}

The lung is a primary target for inhaled oxidants generated naturally during the combustion of oxygen and after inhalation of atmospheric pollutants (Mossman 2003). Lately attention has been given to reactive oxygen species (ROS) generation in lung damage (Castranova et al., 2002, Shukla et al., 2003). ROS may interact with cellular protein, lipid, and DNA, causing alterations in the target cell function. Also the presence of several polycyclic aromatic hydrocarbons (PAHs), (benzo (a) pyrene (B (a) $\mathrm{P})$, benz (a) anthracene $(\mathrm{B}(a) \mathrm{A})$, and dibenz $(a, h)$ anthracene $(\mathrm{B}(a, h) \mathrm{A})$ in the $\mathrm{COF}$ sample is a measure of the potential for cellular injury through hydroxyl radical generation (Wu et al.,1998). Based on this, the changes that occurred in lungs and liver may be due to the presence of the PAHs in the cotton oil fumes which increase the free radicals and ROS in lungs and liver tissues.

The excess free radicals, for example, hydroxyl radicals, superoxide anions and hydrogen peroxide combined with some ions can cause DNA damage or indirectly form free radicals in the cell membrane; leading to lipid peroxidation (Guidarelli et al., 1997). A substantially high level of endogenous lipid peroxidation is an indicator of biochemical disorder in cells, tissues, and organs, as well as an indicator of the toxicological effect of some chemical toxins on living organisms (Gupta et al., 1991). Also, free radicals trigger lipid peroxidation chain reactions by extracting a hydrogen atom from a side-chain methylene carbon, which results in a carbon-centered lipid radical. During the process of lipid peroxidation, the byproducts generated (i.e. molandialdehyde and lipid peroxides) may enhance the process of lipid peroxidation (Halliwell and Gutteridge 1999, Bakan et al., 2002 and Taysi et al., 2003).As in the present study, cotton cooking oil fumes, may exert its toxic effects through oxygen radicals initiated chain reactions that lead to lipid oxidation and peroxidation in lung and liver tissues and hence increase their MDA levels after COF exposure.

The increased susceptibility of highly unsaturated membrane phospholipids to free radicals initiated its oxidation and the role of vitamin $\mathrm{E}$ in preventing initiation and propagation of the lipid peroxidation is important (Chow 1991 and Valk and Hornstra 2000). So, the present data showed that, the decreased of phospholipids and the total 
lipids may be due to the increase of lipid peroxidation in lung and liver tissues of cotton oil fumes exposed groups.

On the other hand, SOD and CAT participate in cellular protection against lipid peroxidation in vivo by removing the potential initiators of the peroxidative processes, i.e., $\mathrm{O}_{2}^{-}, \mathrm{H}_{2} \mathrm{O}_{2}$ and possibly other peroxides as well (Sirtori et al., 1992). This mean the oxidative stress in the lung and liver tissues resulted from decreases of SOD and CAT activities which accompanied with increase in MDA in both lung and liver tissues. Both the enzyme activity and the synthesis of DNA and protein are then inhibited (Esterbauer et al., 1991), this may be explained why both total protein contents and SOD and CAT activities were decreased in the lung and liver after the COF exposure.

GST is a major cellular phase II detoxification enzyme (Sundberg et al., 1997), and it plays a defense role against the carcinogenic effect (Sundberg et al., 2002). The generation of lipid peroxidation products has been associated with depletion in GSH levels (Gul et al., 2000), as in the present data, there was a significantly decrease in lung and liver GSH after COF treatment, especially after 60 days of exposure. In lung airway surface liquid, GSH is thought to play a major role in antioxidant defense (Govindaraju et al., 2003). So, GST, which plays an important role in conjugating the metabolites resulting from the action of cytochrome $\mathrm{P}_{450}$, with GSH (Den Boer et al.,1990b, Sweet and Blanchard 1991), favoring their elimination from the body of organisms, is a critical detoxification enzyme (Hartman and Shankel 1990). The over oxidation of GSH by the ROS can inhibit the activities of glutathione S-transferase, and this may be explained their decrease in the lung and liver tissues after COF exposure.

MDA can easily form adducts with the thiol group of many amino acids to produce the carbonyl groups of protein (Esterbauer et al., 1986). Not only MDA, but also other reactive Oxygen species can modify amino acid side-chains from protein aggregates, cleavage peptide bonds, and make protein more susceptible to proteolytic degradation (Halliwell and Gutteridge 1999). So, serum amino acids levels were significantly decreased after both 30 and 60 days of treatment.

Reactive oxygen species have been reported to play a role in carcinogenesis by inducing oxidative DNA damage (Trush and Kensler 1991).So, DNA damage caused by cotton cooking oil fumes is related to the production of excess free radicals and ROS, as Fenton reaction is responsible for DNA damage produced under oxidative stress, superoxide anion behaves as an iron reducing species in the production of 8-oxo-29deoxyguanosine, a DNA lesion produced by 'OH (Mao et al., 1993). A higher formation of MDA was, therefore, believed to be related to the induced cytotoxicity and genotoxicity effects on lung tissue by oil fumes peanut oil (Wu and Yen 2004), it may spontaneously react with nucleophilic centers in the cell and thereby covalently bind to DNA, RNA, and protein (Yin et al., 1995, Rikans and Hornbrook 1997).

The cotton oil fumes exposed rats increase the MDA which may induce the cytotoxcity and genotoxicity in the lung in 60 days group than in 30 days group, this was reflected in molecular changes, as an induced gene mutation that can be described by the new bands obtained in differential display, RAPD-PCR and SDSPAGE techniques as in fig $(1,2$, and 3$)$. In fig (1) control gave two bands in low molecular weights but the exposed groups contain a band at molecular weight more than $500 \mathrm{bp}$. The presence of this band may be due to an induction of the P35 gene that was expressed when the rats exposed to the cotton oil fumes. This means that, the cotton oil fumes made induction for the oncogene to cause the cancer disease in the rat lung. The molecular tools gave good indication for the DNA changes which carried out due to the cancer infection and also the changes reflected by protein patterns. As well as, small deviations from the physiological activity of antioxidant enzymes and nonenzy- matic antioxidant systems may have a dramatic effect on the resistance of cells to oxidant-induced damage to the genome and cell killing (Dedon et al., 1998 and Limoli et al., 1998). 
Alpha tocopherol exhibited the greatest activity of antioxidation in cooking oils when compared to the other natural antioxidants. The preventive effect of vita$\min \mathrm{E}$ for the reduction of mutagenicity and amounts of PAHs and NPAHs of fumes from cooking oils were evaluated (Tsai and Huang 1993). However, vitamin E may exert its action, namely by scavenging peroxyradicals and thereby acting as a chainbreaking antioxidant (Serbinova et al., 1991), and prevent initiation and propagation of the lipid peroxidation (Valk and Hornstra 2000), this may be explain the regression in lung and liver MDA levels in the fumes exposed and protected groups. Different groups have reported the effects of antioxidant supplementation on lipid peroxidation (Ibrahim et al., 1999). It has been suggested that Vitamin E stabilizes the cell membrane through interaction of its phytyl side chain with the polyunsaturated fatty acyl groups of phospholipids (Valk and Hornstra 2000), consequently, it prevent its oxidation after fumes exposure in both lung and liver tissues. So, vitamin E protects PUFAs and protein thiol groups against oxidation (Ferre et al., 2001), these lead to amelioration of total lipids and protein contents after administration of vitamin $\mathrm{E}$ in both lung and liver tissues. Also its administration showed significantly improvement in both amino and nucleic acids in both 30 and 60 days groups. So, the alleviation of most changes in this study support the good explain for the protective role of vitamin $\mathrm{E}$ against the COF exposed rats in both lung and liver tissues.

\section{Conclusion}

Due to the health concern, it is important to increase the oil quality by reducing the mutagenicity and toxicity in the oil fumes. The present results concluded that cotton cooking oil fumes inhalation increased the level of lipid peroxidation in the lungs and liver of rats, accompanied by significant decrease in the activities of SOD, CAT \& GST and concentrations of GSH in the organs tested. Also nucleic acid showed decrease in lung and liver tissues while serum amino acids profile was chang- ed after COF exposure. Also, both of differential display and RAPD-PCR showed an induced gene mutation in the lung tissue after inhalation the cotton oil fumes, so they have a mutagenicity effect on the lung of rats. Protein pattern confirmed the results obtained from the other molecular tools. In addition, the results obtained from Vitamin E showed that it is a good protective antioxidant to avoid the harmful effects of the inhalation of cooking oil fumes. So, the intake of vitamin $\mathrm{E}$ will be efficient for the cookers who exposed for long times to the cooking oil fumes, will be recommended.

\section{References}

1. Aebi, H., (1984): Catalase in vitro. Methods Enzymol., 105, 121-126.

2. Akyol, O., Isci, N., Temel, I., Özgöçmen, S., Uz, E., Murat, M., and Büyükberber, S.,(2001): The relationships between plasma and erythrocyte antioxidant enzymes and lipid peroxidation in patients with rheumatoid arthritis. Joint Bone Spine, 68, 311317.

3. Ames, B.N., and Gold, L.S., (1991): Endogenous mutagens and the causes of aging and cancer. Mutat. Res., 251, 3-16.

4. Baginiski, E.B., Ipstein, E., and Zak, B., (1972): Determination of phospholipids in plasma. Ann. Clin. Lab. Sci., 2, 255-260.

5. Bakan, N., Taysi, S., Yılmaz, O., Bakan, E., Kuskay, S., Uzun, N., and Gundogdu, M.,(2003): Glutathione peroxidase, glutathione reductase, superoxide dismutase activies, glutathione, nitric oxide, and malondialdehyde levels in serum of patients with chronic lymphocytic leukaemia, Clin. Chem. Acta, 338 143-149.

6. Burton, G. W., and Traber, M. G., (1990): Vitamin E: antioxidant activity, biokinetics and bioavailability. Annu. R. Nutr., 10, 357-382.

7. Castranova, V., Porter, D., Millecchia, L., Ma, J.Y., Hubbs, A.F., and Teass, A., (2002): Effect of inhaled crystalline silica in a rat model: time course of pulmonary reactions. Mol. Cell. Biochem., 234-235, 12,177-84.

8. Chiang, T. A., Wu, P. F., Wang, L. F., Lee, h., Lee, C. H., and Ko, Y. C., (1997): Mutagenicity and polycyclic aromatic hydrocarbon content of fumes from heated cooking oils produced in Taiwan. Mutation Res., 381, 157-161. 
9. Chow, D. K., (1991): Vitamin E and oxidative stress. Free Radical Biology and Medicine, 11, 215-232.

10. Coggon, D., Panneft, B., Osmond, C., and Acheson, E.D., (1986): A survey of cancer and occupation in young and middle aged men.I. Cancers of the respiratory tract, Br. J. Ind. Med. 43, 332-338.

11. Cohen, A. J., and Pope, C. A. III. (1995): Lung cancer and air pollution. Environ. Health Perspect., 103, 219-224.

12. Dedon, P.C., Plastaras, J.P., Rouzer, C.A., and Marnett, L.J., (1998): Indirect mutagenesis by oxidative damage: formation of the pyrimidopurinone adduct of deoxyguanosine by base propenal. Proc Natl Acad Sci, 95, 11113-11116.

13. Den Boer, P.J., van Loon, A.A., Mackenbach, P., van der Schans, G.P., and Grootegoed, J.A., (1990b): Effect of glutathione depletion on the cytotoxicity of xenobiotics and induction of single-strand DNA breaks by ionizing radiation in isolated hamster round spermatids .J Reproduction and Fertility 88, 259-269.

14. Dische, Z., and Schwartz, K., (1977): Bioinformatics (genomics). Mikrochim. Acta, 2, 13.

15. Dorger, M., Allmeling, A.M., Kiefmann, R., Munzing, S., Mesmer, K., and Krombach, F., (2002): Early inflammatory response to asbestos exposure in rat and hamster lung: role of inducible nitric oxide synthase. Toxicol. Appl. Pharmacol. 181, 93-105.

16. Esterbauer, H., Benedetti, A., Lang, J., Fulceri, R., and Fauler, G., (1986): Comporti M. Studies on the mechanism of formation of 4-hydroxynonenal during microsomal lipid peroxidation. Biochim. Biophys. Acta., 21,876, 1, 54-66.

17. Esterbauer, H., Dieber-Rotheneder, M., Striegl, G., and Waeg, G., (1991): Role of vitamin $\mathrm{E}$ in preventing the oxidation of low-density lipoprotein. Am J Clin Nutr., 53, 1, 314-321.

18. Ferre, N., Camps, J., Paul, A., Carbre, M., Calleja,L., Osada, J., and Joven, J., (2001): Effects of high-fat, low cholesterol diets on hepatics lipid peroxidation and antioxidants in apolipoprotien E-efficient mice. Molec- ular and Cell Biochemistry, 218, 165-169.

19. Frings, C.S. Fendley, T.W. Dunn, R.T., and Queen C. A., (1972): Improved determination of total serum lipids by the sulfo-phospho-vanillin reaction. Clin Chem, 18(7), 673-674.
20. Govindiaraju, K., Govindaraju, V., and Eidelman, D.H., (2003): Analysis of glutathione in rat airway surface liquid by capillary zone electrophoresis with conductivity detection.JChromatography B.788,369-376.

21. Guidarelli,A.,Cattabeni, F., and Cantoni, O.,(1997): Alternative mechanisms for hydroperoxideinduced DNA single strand breakage. Free Radic. Res.J.26, 6, 537-547.

22. Gul, M. Kutay, F.Z. Temocin, S. and Hanninen, O., (2000): Cellular and clinical impli- cations of glutathione, Indian J. Exp. Biol. 38, 625-634.

23. Gupta, A., and Hasan, M., Chander, R., and Kapoor, N.K., (1991): Age-related elevation of lipid peroxidation products: diminution of superoxide dismutase activity in the central nervous systems of rats.Gerontology. 37, 305-309.

24. Habig, W.H., and Jakoby, W.B., (1981): Assay for differentiation of glutathione Stransferases. Methods Enzymol. 77, 398405.

25. Halliwell, B., and Gutteridge, J.M.C., (1999): Free Radical in Biology Medicine. Oxford University Press, London. Zhang, Q., Huang, X., 2002. Induction of ferritin and lipid peroxidation by coal samples with different prevalence of coal workers' pneumoconiosiss: role of iron in the coals. Am. J. Ind. Med. 42, 171-179.

26. Harris, S.A., (1995): Systematic and randomly amplified polymorphic DNA in the genus Leucaena Benth. (Mimosoideae, Legumi-nosae). Plant Systematic and Evol., 197,195-208.

27. Hartman, P.E., and Shankel, D.W., (1990): Antimutagens and anticarcinogens; a survey of putative interceptor molecules. Environ. Molecular Mutagenesis 15,145182.

28. Henery ,R.J., (1964): Determination of total protein, colorimetric method. Clin. Chem. Harper and Row Publishers, New York, 181.

29. Ibrahim, W., Lee, U., Szabo, J., Bruckner, G., and Chow, C.K., (1999): Oxidative stress and antioxidant status in mouse kidney: effects of dietary lipid and vitamin $\mathrm{E}$ plus iron. J. Nutritional Biochemistry, 10, 674-678.

30. Iqbal, M., Rezazadeh, H., Ansar, S., and Athar, M., (1998): Alphatocopherol (Vitamin E) ameliorates ferric nitrilotriacetate (Fe-NTA)-dependent renal proliferative response and toxicity: diminution of oxidative stress. Hum. Exp. Toxicol., 17, 3, 163-171. 
31. Iwagawa, M., Maeda, T., Izumi, K., Otsuka, H., Nishifuji, K., Ohnishi, Y., and Aoki, S., (1989): Comparative doseresponse study on the pulmonary carcinogenicity of 1,6-dinitropyrene and benzo[a]pyrene in F344 rats. Carcinogenesis 10, 1285-1290.

32. Ko, Y.C., Cheng, L.S., Lee, C.H., Huang, J.J., Huang, M.S., Kao, E.L., Wang, H.Z., and Lin, H.J., (2000): Chinese food cooking and lung cancer in women nonsmokers. Am J Epidemiol. 15, 151, 140-147.

33. Kuo, C.Y., Chen, C.Y., Cheng, Y.W., and Lee, H. (1998): Correlation between the amounts of polycyclic aromatic hydrocarbons and mutagenicity of airborne particu- late samples from Taichung City, Taiwan, Environ. Res. 78, 43-49.

34. Laemmli, U. K., (1970): Cleavage of structural proteins during the assembly of the head of bacteriophage T4. Nature, 227, 5259, 680-685.

35. Larson, R. A., Lloyd, R. A., Marley, K. A., and Tuveson, R. W., (1992): Ferricion-photosensitized damage to DNA by hydroxyl and non-hydroxyl radical mechanism, J. Photochem. Photobiol. B. Biol. 14, 245-247.

36. Li, S., Pan, D., and Wang, G., (1994): Analysis of polycyclic aromatic hydrocarbons in cooking oil fumes. Arch. Environ. Health 49, 119-122.

37. Limoli, C.L., Hartmann, A., and Shephard, L., (1998): Apoptosis, reproductive failure, and oxidative stress in chinese hamster ovary cells with compromised genomic integrity. Cancer Res, 58, 3712-3718.

38. Mao, G.D., Thomas, P.D., Lopaschuk, G.D., and Poznansky, M.J., (1993): Superoxide dismutase (SOD)-catalase conjugates. Role of hydrogen peroxide and the Fenton reaction in SOD toxicity. J Biol. Chem., 268, 416-20.

39. Max, J.L., (1987): Oxygen radical linked to many diseases. Science 235, 529-531.

40. McBride, T.J. Preston, B.D., and Loeb, L.A. (1991): Mutagenic spectrum resulting from DNA damage by oxygen radicals, Biochem. 30, 207-213.

41. Mejabaum, W., (1939): Uber die best immung kleiner pentolosemngen insebessondere in derivation der adenylsaure. Z. Physiol.Chem., 258,117.

42. Mossman, B.T., (2003): Introduction to serial reviews on the role of reactive oxygen species (ROS/RNS) in lung injury and diseases. Free Radical Biol. Med. 34, 115-116.

43. Mossman, B.T., and Churg, A., (1998): Mechanisms in the pathogenisis of asbestosis and silicosis. Am. J. Respir. Crit. Care Med. 157, 1666-1680.

44. Mumford, JL., Li, X., Hu, F., Lu, XB., and Chuang, JC., (1995): Human exposure and dosimetry of polycyclic aromatic hydrocarbons in urine from Xuan Wei, China with high lung cancer mortality associated with exposure to unvented coal smoke. Carcinogenesis 16, 3031-3036.

45. Nikishimi, M., Rao, N.A., and Yagi, K., (1972): The occurrence of superoxide anion in the reaction of reduced phenazine methosulafate and molecular oxygen. Biochem. Biophys. Res. Commun. 46, 849-854.

46. Oesch, F., (1984): Metabolism of carcinogens, possibilities for modulation. Acta Pharmacol. Toxicol. (Copenh), 55, 15-33.

47. Ohkawa,H., Ohishi,N., and Yagi,K., (1979): Assay for lipid peroxidation in animal tissues by thiobarbituric acid reaction. Anal. Biochem., 95, 35-358.

48. Phillips, B. J., James, T. E. B., and Anderson, D., (1984): Genetic damage in $\mathrm{CHO}$ cells exposed to enzymatically generate active oxygen species. Mutat. Res. 126, 265-271.

49. Prins, H.K., and Loose, J.A., (1969): Glutathione in biochemical methods in red cell genetics. Academic Press, N.Y.D. London., 126-129.

50. Quiles, J. L., Ramirez-Tortosa, M. C., Gomez, J. A., Huertas, J. R., and Mataix, J., (2002): Role of vitamin E and phenolic compounds in the antioxidant capacity, measured by ESR, of virgin olive, olive and sunflower oils after frying. Food Chemistry, 76, 4, 461-468.

51. Rikans, L.E., and Hornbrook, K.R., (1997): Lipid peroxidation, antioxidant protection and aging. Biochim. Biophys. Acta, 1362, 116-127.

52. Seaton, A., MacNee, W., Donaldson, K., and Godden, D. (1995): Hypothesis: Particulate air pollution and acute health effects. Lancet 345, 176-178.

53. Serbinova, E., Kagan, V., Han, D., and Packer, L., (1991): Free radicals recycling and intramembrane mobility in the antioxidant properties of alpha-tocopherol and alpha-tocotrienol. Free Radical Biology and Medicine. 10, 263-275.

54. Shields, P.G., Xu, G.X., Blot, W.J., Fraameni, J.J.F., Trivers, G.E., 
Dellizzari, E.D., Qu, Y.H., Gao, Y.T., and Harris, C.C., (1995): Mutagens from heated Chinese and U.S. cooking oils, J. Natl. Cancer Inst. 87, 836-841.

55. Shukla, A., Gulumian, M., Hei, T.K., Kamp, D., Rahman, Q., and Mossman, B.T., (2003): Multiple roles of oxidants in the pathogenisis of asbestos-induced diseases. Free Radical Biol. Med. 34,1117-1129.

56. Sirtori,C. R., Gatti, E., Tremoli, E., Galli, C., Gianfranceschi, G., Franceschini, G., Colli, S., Perego, P., and Stragliotto, E., (1992): Olive oil, corn oil, and n-3 fatty acids differently affect lipid, lipoproteins, platelets, and superoxide formation in type II hypercholesterolemia. Amer. J. Clin. Nutr., 56, 113-122.

57. Strange, R.C., Spiteri, M.A., Ramachandran, S., and Fryer, A., (2001): Glutathione-S-transferase family of enzymes. Mutat. Res. 482, 21-22.

58. Sundberg, K., Dreij, K., Seidel, A., and Jernstrom, B., (2002): Glutathione conjugation and DNA adduct formation of dibenzo [a,l] pyrene and benzo[a] pyrenediolepoxides in V79 cells stably expressing different human glutathione transferases, Chem. Res. Toxicol. 15, 170-179.

59. Suzuki,K.,and Hei,T.K., (1996): Induction of heme oxygenase in mammalian cells by mineral fibers:Distinctive effect of reactive oxygen species.Carcinogenesis17,661-667.

60. Sweet, W.L., and Blanchard, J.S., (1991): Human erythrocyte glutathione reductase: chemical mechanism and structure of the transition state for hydride transfer. Biochem. 30, 8702-8709.

61. Taysi, S. Koc, M. Buyukokuroglu, M.E. Altinkaynak, K., and Sahin, Y.N., (2003): Melatonin reduces lipid peroxidation and nitric oxide during irradiation-induced oxidative injury in the rat liver, J. Pineal. Res. 34, 173-177.

62. Teramoto,S.,Uejima,Y.,andTeramoto,K., (1996): Effect of age on alteration of glutathione metabolism chronic cigarette smoke inhalation in mice. Lung, 174, 119-126.

63. Trush, M.A., and Kensler, T.W., (1991): An overview of the relationship between oxidative stress and chemical carcinog-enesis. Free Radic Biol Med., 10, 3-4, 201-209.

64. Tsai, W.B., and Huang, P.C., (1993): Analysis of variously saturated fatty acid contents in some high fat commercial processed foods, Food Sci. 20, 178-186.

65. Tunga, U. H., Ko, J.L., Liang, Y.F., Yin L., Pu Y., and Lin, P., (2001): Cooking oil fume-induced cytokine expression and oxidative stress in human lung epithelial cells. Environmental Research Section A, 87, 47-54

66. Valk, E. E., and Hornstra, G., (2000): Relationship between vitamin E requirement and polyunsaturated fatty acid intake in man: a review. International J.Vitamin and Nutrition Res., 70, 31-42.

67. Wagner, B.A., Buettner, G.R., and Burns, C.P., (1996): Vitamin E slows the rate of free radical-mediated lipid peroxidation in cells. Arch. Biochem. Biophys. 334 (2), 261-267.

68. White, J. W., and Castillo, J. A., (1990): Association between productivity, root growth and carbon isotope discrimination in Phaseolus vulgaris under water deficit. Australian J. Plant Physiol. 17,2, 189-198.

69. Williams, J.G.K., Hanafey, M. K., Rafalski, J.A., and Tingey, S.V., (1993): Genetic analysis using random amplified polymorphic DNA markers. Methods Enzymol., 218,704-740.

70. Winder, K., and Eggum, O. B., (1966): Protein hydrolysis. A description of the method used at the department of animal physiology in Copenhagen. Acta Agriculture Scandinavia, 16,115.

71. Witschi, H., Espiritu, I., Maronpot, R. R., Pinkerton, K. E., and Jones, A. D., (1997): The carcinogenic potential of the gas phase of environmental tobacco smoke. Carcino- genesis 18, 2035- 2042.

72. Wu, P.F., Chaing, T.A., Wang, L.F., Chang, C.S., and Ko, Y.C., (1998): Nitropolycyclic aromatic hydrocarbon contents of fumes from heated cooking oils and prevention of mutagenicity by catechin. Mutation Res. 403, 29-34.

73. Wu, P.F., Chiang, T.A., Ko, Y.C., Lee, H., (1999): Genotoxicity of fumes from heated cooking oils produced in Taiwan. Environ Res. 80,122-6.

74. Wu, S.C., and Yen, G.C., (2004): Effects of cooking oil fumes on the genotoxicity and oxidative stress in human lung carcinoma (A-549) cells. Toxicol In Vitro. 18(5), 571- 80.

75. Yin,G.Y.,Yin,Y. F., and He, X. F., (1995): Effect of zhuchun pill on immunity and endocrine function of elderly with kidneyyang deficiency. Chung Kuo Chung Hsi I Chieh Ho Tsa Chih, 15, 601-613.

76. Zhang, Z., Shen, H. M., Zhang, Q. F., and Ong,C.N.,(1999): Critical role of GSH in silica-induced oxidative stress, cytotoxicity, and genotoxicity in macrophages. Am. J. Physiol. 277, 743-748. 


\section{دراسة مخاطر أبخرة زيت القطن المستخدم فى الطهى على رئة و كبد الجزذان

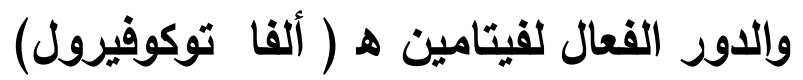

\section{فهمى جاد جاد السعيد}

قسم علم الحيوان, كلية العلوم, جامعة المنصورة

خلصت هذه الدراسـة الى شدة خطورة استتشاق أبخرة زيت قطن الطهى على سـلامة رئة و كبد الجرذان, حيث قامت بدراسة التغيرات الفسيولوجية والجزيئية على الرئة ـ أظهرت النتائج

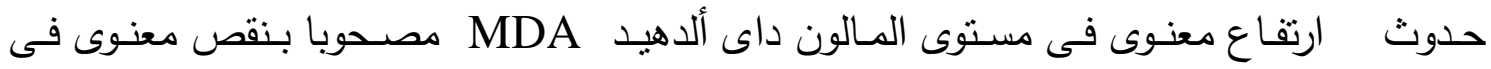
نشاط كل من الكاتاليز CAT , الجلوتاثيون اس نرانسفيريز GST و السوبر أكسيد ديسميوتيز و كذلك تركيز الجلوتاثيون GSH فى رئة و كبد الجرذان المعرضة لأبخرة زيت القطن سواء بعد 30 يوما أو 60 يوما من التعرض. كما حدث نقائ نق حاد في مستوى الأحماض الأمينية

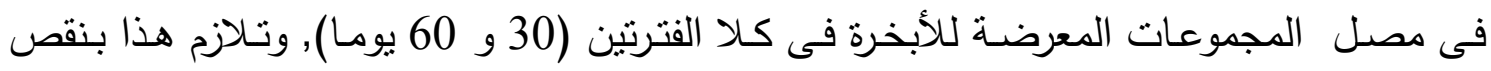

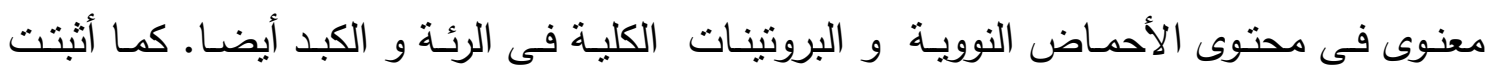

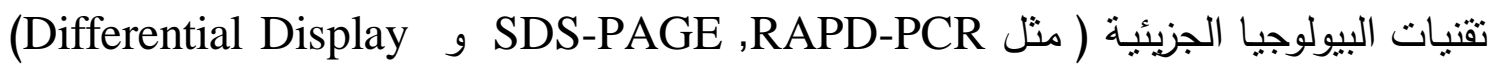
حدوث طفرة جينية مستحثة فى رئة الجرذان بفعل استتشاق هذه الأبخرة و مثل هذه الطفرات ممكن

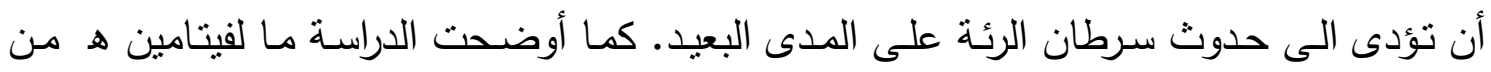
تأثنير معنوى و فعال فى منع حدوث هذه التغيرات بدرجات عالية. لذا توصى الدراسـة أولا بتتاول فيتامين هـ لمن يتعاملون مع زيوت الطهى و خاصة الطهاة , ثانيا عدم المكوث لفترات طويلة فى في الفي المطابخ الغير حسنة التهوية للتقليل من استتشاق هذه الأبخرة شديدة السمية. 